(C) 2019, Emerald Publishing Limited. This accepted manuscript is deposited under

the Creative Commons Attribution Non-commercial International Licence 4.0 (CC BY-NC 4.0).

Any reuse is allowed in accordance with the terms outlined by the licence, here: https://creativecommons.org/licenses/by-nc/4.0/.

To reuse the AAM for commercial purposes, permission should be sought by contacting permissions@emeraldinsight.com.

The final published version is available at https://doi.org/10.1108/JMP-04-2019-0232.

\title{
Co-worker social support and organisational identification: does ethnic self-
}

\section{identification matter?}

\begin{abstract}
Purpose: The purpose of this article is to investigate the role of socially supportive relationships between co-workers in fostering organisational identification. Adopting a Social Identity Theory perspective, the study investigates how employees' ethnic self-identification (ESI) may influence co-worker social support (CWSS)- organisational identification (OID) relationship depending on whether they are indigenes or non-indigenes.
\end{abstract}

Design: Regression analysis was used to examine the relationship between CWSS (independent variable) and OID (dependent variable) at different levels of ESI (moderator variable). Data was collected from 1525 employees from public and private employers in Nigeria.

Findings: Findings supported a positive relationship between CWSS and OID that is moderated by an employee's ESI. Specifically, the study finds that ESI matters in the strength of CWSS-OID relationship such that the relationship is weaker for indigenes compared to nonindigenes.

Originality/value: This study contributes to literature by adding a level of boundary conditions to the overall findings that workplace relationships are important for organisational identification. The study also addresses how employees of different ethnic groups are influenced by the ethnicity of the context prevailing where an organisation is located

Practical implications: As organisations develop policies that increase the representation of various ethnic groups or other forms of social identities at work, there is need to create an environment that fosters socially supportive relationships among co-workers.

Keywords: Co-worker social support, ethnic self-identification, indigenes/non-indigenes, Nigeria, organisational identification 
(C) 2019, Emerald Publishing Limited. This accepted manuscript is deposited under

the Creative Commons Attribution Non-commercial International Licence 4.0 (CC BY-NC 4.0).

Any reuse is allowed in accordance with the terms outlined by the licence, here: https://creativecommons.org/licenses/by-nc/4.0/.

To reuse the AAM for commercial purposes, permission should be sought by contacting permissions@emeraldinsight.com. The final published version is available at https://doi.org/10.1108/JMP-04-2019-0232.

\section{Introduction}

Perceptions of workplace relationships among co-workers have been well researched and there is strong support demonstrating the positive influence it has on employees' view of team/workgroup membership and performance at work (Andrews and Mostafa, 2017; Cole et al., 2016). However, current perspectives insufficiently acknowledge the influence that context (such as employee ethnicity and organisational location) might play on organisational relationships (Farmer et al., 2015; Sluss and Ashforth, 2007). In this study therefore, we extend the literature by examining boundary conditions to existing findings, specifically by empirically investigating the influence of ethnic self-identification (ESI) and ethnic congruence on the relationship between co-worker social support (CWSS) and organisational identification (OID).

Co-worker social support is the perception that employees have that their co-workers at a unit or work team level appreciate their contributions and care about their wellbeing (Frenkel, Restubog, and Bednall, 2012). When employees experience positive CWSS, they reciprocate by giving extra role support and work related stress is reduced (Caplan et al.,1975,Hwa, 2012, Md-Sidin et al., 2010). Although recent studies examining the effect of CWSS have found a reciprocal relationship between CWSS and employee identity with a group (e.g. Farmer et al., 2015; Sluss and Ashforth, 2007), they have been limited to CWSS influence on employeees' identification with their co-workers at their units or work team level. The relationship between CWSS and an employee's identification with their organisation remains unexplored (Farmer and Van- Dyne, 2010). We extend these lines of enquiry by investigating co-worker social support and organisational identification relationships. 
(C) 2019, Emerald Publishing Limited. This accepted manuscript is deposited under

the Creative Commons Attribution Non-commercial International Licence 4.0 (CC BY-NC 4.0).

Any reuse is allowed in accordance with the terms outlined by the licence, here: https://creativecommons.org/licenses/by-nc/4.0/.

To reuse the AAM for commercial purposes, permission should be sought by contacting permissions@emeraldinsight.com. The final published version is available at https://doi.org/10.1108/JMP-04-2019-0232.

Organisational identification refers to an employee's feeling of sense of belonging to an organisation (Asatryan and Oh, 2008). It involves a psychological process where employees attribute an organisation's identity to their own to the extent that the organisation becomes a source of self-definition (Ashforth et al., 2008). It is important to explore ways to foster OID because of the positive consequences it has for an organisation, such as improved performance and retention of talents (Ellemers and Haslam, 2005, Judge and KammeyerMueller, 2012, Marique and Stinglhamber, 2011).

A further strand of investigation is the influence that ethnic self-identification (ESI) may have on these relationships. ESI refers to a sense of commitment to one's ethnic heritage (D'Hondt et al., 2017). Despite the importance of ESI in relationships at work in multi-ethnic settings ( King et al., 2012; Triana et al., 2012) because of their importance to employees’ identities and behavioural patterns (Nyambegera, 2002), research conclusions have not hitherto addressed how different ethnic groups are influenced by the ethnicity of the context prevailing where the organisation is located (Agbiboa, 2012; Pratt, 1998).

\section{About the setting}

As a multi-ethnic society, Nigeria provides a suitable context for this empirical study because of its large number of ethnic groups (Oruwari et al., 2004). In a bid to foster coexistence among various ethnic groups (now represented by States and Local Government Areas (LGA)), the government legislated the Federal Character Principle (FCP)(Kendhammer, 2014) which mandates organisations, especially those in the public sector to have employee compositions that 'mirror' the society (Adeosun, 2011, Kendhammer, 2014). In Nigeria, ethnic identification is manifested in terms of identification with a region (State at the federal level and LGA at the State level) of origin (Olatokun and Nwafor, 2012). People who originate from a given State are normally referred to as 
(C) 2019, Emerald Publishing Limited. This accepted manuscript is deposited under

the Creative Commons Attribution Non-commercial International Licence 4.0 (CC BY-NC 4.0).

Any reuse is allowed in accordance with the terms outlined by the licence, here: https://creativecommons.org/licenses/by-nc/4.0/.

To reuse the AAM for commercial purposes, permission should be sought by contacting permissions@emeraldinsight.com. The final published version is available at https://doi.org/10.1108/JMP-04-2019-0232.

"indigenes", while those who originate from another State but reside in the State are classed as "non-indigenes".

Existing studies have credited the FCP with fostering some level of social cohesion (Gberevbie, 2010, Ukiwo, 2005, Musa, 2015). However, studies have not specifically explored its implications for organisations. To extend the understanding of the FCP within organisational setting, we consider that the relationships between CWSS, OID and ESI will be different for indigenes and non-indigenes as their affiliations to their home ethnicity will influence their work relationships.

The remainder of this paper is structured as follows: first, the paper presents the theory underpinning CWSS-OID relationship. Secondly, the design of the study is reported and a description of the scales that is used to measure the variables. Findings from the data analysis are presented in the third section. Discussions and conclusions are presented at the end.

\section{Theoretical development and hypothesis}

Organisational identification may be explained using a Social Identity Theory (SIT) approach because group membership can be considered to be a form of self-identification (Ashforth and Mael, 1989). Social identity theorists recognise that employees may have multiple sources of identity, linked to the groups they belong to (Tajfel, Turner, Austin, and Worchel, 1979) such as family, social class, organisation and ethnicity. SIT predicts that group memberships have the potential to provide a source of pride, self-esteem and sense of belonging to individuals (Tajfel et al., 1979). The theory is relevant in the organisational context in that organisations form a multi-ethnic space in which a strong auto-ethnic identification can influence the broader dynamics of relationships at work (McKay and Avery, 2015). 
(C) 2019, Emerald Publishing Limited. This accepted manuscript is deposited under

the Creative Commons Attribution Non-commercial International Licence 4.0 (CC BY-NC 4.0).

Any reuse is allowed in accordance with the terms outlined by the licence, here: https://creativecommons.org/licenses/by-nc/4.0/.

To reuse the AAM for commercial purposes, permission should be sought by contacting permissions@emeraldinsight.com. The final published version is available at https://doi.org/10.1108/JMP-04-2019-0232.

\section{Co-worker social support and organisational identification}

Relationships with co-workers are integral dimension of an employee's working life and research has demonstrated that they influence the extent to which individual employees identify with a team/workgroup (Farmer et al., 2015; Sluss and Ashforth, 2007). Although workplace relationships are predominantly experienced at localised team/workgroup levels, employees may perceive the care and support from co-workers as a core organisational value (Gountas et al. 2014). Thus, from an employee's perspective, CWSS is perceived as the reification of organisational intent (Chughtai, 2016; Consiglio et al., 2016, Rice, 2006).

The positive affect derived by CWSS heightens a sense of belonging to and pride in the organisation. Through this mechanism, employees become emotionally connected to the organisation to the extent of attributing the organisations identify to theirs (Nelson and Quick, 1991). Employees who experience positive CWSS may not only speak well of and defend their work team/group but extend same to the organisation itself (Bennett and Stamper, 2001). Thus, we expect the following relationship between CWSS and OID in the context of our study:

H1. Co-worker social support has a positive relationship with organisational identification.

\section{The moderating role of ethnic self-identification}

Organisations do not operate in a social or cultural vacuum and external societal norms that arise from diverse ethnic groups in the society may spill over into the workplace, influencing both how employees behave themselves and also perceive their own treatment from colleagues, especially those from a different ethnic group ( Lee and Reade, 2015; Pugh et al., 2008). It is for this reason that we examine ethnic self-identification as a potential moderator of the relationship between co-worker social support and organisational identification. ESI is an individual difference that describes the degree to which membership of an ethnic group 
(C) 2019, Emerald Publishing Limited. This accepted manuscript is deposited under

the Creative Commons Attribution Non-commercial International Licence 4.0 (CC BY-NC 4.0).

Any reuse is allowed in accordance with the terms outlined by the licence, here: https://creativecommons.org/licenses/by-nc/4.0/.

To reuse the AAM for commercial purposes, permission should be sought by contacting permissions@emeraldinsight.com. The final published version is available at https://doi.org/10.1108/JMP-04-2019-0232.

informs a person's concept of self (Phinney and Ong, 2007). In an organisational setting, a person with high ESI might seek to ascertain colleagues' ethnic backgrounds and assess colleagues' values and emotional significance of being part of their ethnic group (Tajfel, 1974). As a powerful source of self-identification (Doan and Stephan, 2006), ESI is therefore expected to moderate the relationship between CWSS and OID, such that individuals with high ESI are less likely to be influenced by positive co-worker support than individuals with low ESI. We therefore hypothesise that:

H2. ESI moderates CWSS-OID relationship such that there will be a weaker relationship between CWSS and OID for employees with higher ESI

Furthermore, in addition to the general expectation of ESI as a moderator of CWSSOID relationship, it is important to recognise the prevailing ethnicity in the organisational context. In this study, two broad categories of ethnic composition are relevant: indigenes (employees who originate from the same State as the organisation is located) and nonindigenes (employees who originate from outside the State where the organisation is located). When there is congruence between employee ethnicity and prevailing State/organisation ethnicity we expect the interaction effect of CWSS and ESI on OID to be reduced. This theorisation is supported by the SIT framework. Within SIT, both organisational affiliation and ethnicity as forms of social grouping have the potential to make competing demands on employees' overall self-identification (Barron et al., 2011). In a context of ethnic similarity between the employee and an organisation (indigenes), the potential tensions arising from ethnic difference are not expected to be activated (Pittman et al., 2014). However, when an employee's ethnicity is different from the ethnicity prevailing where their organisation is located (non-indigenes), the potential for tension between ethnic self-identification and OID is expected to be higher (Phinney et al., 2001). In this context, latent ethnic self- 
(C) 2019, Emerald Publishing Limited. This accepted manuscript is deposited under

the Creative Commons Attribution Non-commercial International Licence 4.0 (CC BY-NC 4.0).

Any reuse is allowed in accordance with the terms outlined by the licence, here: https://creativecommons.org/licenses/by-nc/4.0/.

To reuse the AAM for commercial purposes, permission should be sought by contacting permissions@emeraldinsight.com. The final published version is available at https://doi.org/10.1108/JMP-04-2019-0232.

identification is expected to be activated for the relationship between co-worker social support and organisational identification. Therefore, we hypothesise:

H3. The moderation effects of ESI on CWSS-OID relationship is weaker for indigenes than for non-indigenes

\section{Method}

\section{Participants description}

Six organisations based in one Nigerian State participated in the study. Four were from the public sector (education, health, power, and finance) and two were from the private sector (manufacturing and retail). Data were collected from 1525 individual employees (participants) in these organisations via a paper-based questionnaire. $908(59.5 \%)$ respondents were employed in public sector organisations and 617 (40.5\%) respondents were employed in private sector organisations.

For the public sector participants, 817 (90\%) of respondents originated from the State (indigenes) and (91) 10\% were Nigerian citizens and employed in the State but did not originate from the State (non-indigenes). $80 \%$ of respondents had worked for their employer for over five years. $62 \%$ of respondents were categorised as senior staff, and above. In the private sector employees, $279(45 \%)$ of respondents were indigenes and $338(55 \%)$ were nonindigenes. $62 \%$ of the employees had worked for their employer for over five years. $64 \%$ of respondents were categorised as senior staff and above.

\section{Measures}

\section{Co-worker social support}

A four item instrument was adapted from the co-worker social support scale provided by Caplan et al. (1975). The instrument used a five-point Likert scale: (1) strongly disagree and 
(5) strongly agree. An example statement includes: 'I know I can rely on my colleagues when things get tough at work' The scale reported a Cronbach alpha of 0.75 for the four-items.

\section{Organisational identification}

The five-item organisational identification (OID) scale from Mael and Ashforth (1992) was used. The instrument used a five-point Likert scale: (1) strongly disagree and (5) strongly agree. An example statement includes: 'When I talk about my organisation, I usually say 'we', rather than 'they', The Cronbach alpha for the five-item scale was 0.80 .

\section{Ethnic self-identification}

A multi group ethnic identity measure (RMEIM) scale proposed by Phinney (1992) and revised by Phinney and Ong (2007) was used to measure ethnic self-identification. The instrument used a five-point Likert scale: (1) strongly disagree and (5) strongly agree. An example statement includes: 'I consider my State affiliation important'. The Cronbach alpha for the six-item scale was 0.84 .

\section{Indigenes/non-indigenes}

Participants indicated their State of Origin on the questionnaire. 1096 indicated that they were indigenes (that is, native to the State), while 429 were non-indigenes (that is, non-native to the State).

\section{Control variables}

We controlled for tenure in the organisation (employed for 5 years and below $=1$, more than 5 years to 10 years $=2$ and greater than 10 years $=3$ ), sector $($ public sector $=1$ and private sector $=2$ ) and position in organisation (junior staff $=1$ and senior staff $=2$ ). Tenure in organisation was controlled for in line with theorisation that employees who have spent longer time in employment may have formed networks at work and as such have higher OID 

The final published version is available at https://doi.org/10.1108/JMP-04-2019-0232.

(Pittman et al., 2014). Sector was included as formalisation of the FCP in public sector organisations may influence how employees perceive OID compared to those in the private sector (Goulet and Frank, 2002). We also controlled for position in organisation because of findings that suggest that senior level employees may place less value ethnic selfidentification compared to junior level employees and as such may experience lower OID (Barak et al., 1998).

\section{Results}

The analytical approach adopted a two-stage process. First, using Hayes (2013) process model, the relationship between co-worker social support and organisational identification was tested. Second, the moderating effects of ethnic self-identification on the relationship between co-worker social support and organisational identification were examined. We also examined the moderation effect of ESI on CWSS-OID relationship separately in indigene and non-indigene samples.

Table 1 shows means, standard deviation and correlations between the principal and control variables. There were significant correlations between the principal variables although these were judged to exhibit limited collinearity because the bivariate correlations were not close to the maximum value of 0.8 (Prieto-Pastor \& Martin-Perez, 2015). The data were tested for multicollinearity and yielded the following variance inflation factors (VIF); ethnic self-identification 1.660, co-worker social support 1.148 and organisational identification 1.763. A VIF value lower than 3 suggests that there is no multicollinearity error (Alin, 2010).

Insert Table 1 about here 
(C) 2019, Emerald Publishing Limited. This accepted manuscript is deposited under

the Creative Commons Attribution Non-commercial International Licence 4.0 (CC BY-NC 4.0).

Any reuse is allowed in accordance with the terms outlined by the licence, here: https://creativecommons.org/licenses/by-nc/4.0/.

To reuse the AAM for commercial purposes, permission should be sought by contacting permissions@emeraldinsight.com. The final published version is available at https://doi.org/10.1108/JMP-04-2019-0232.

To ascertain the extent to which the items used represent the unobservable variables in the construct, Average Variance Extracted (AVE) and Composite Reliability Index (CRI) (Hair et al., 2012) were calculated. The rule of thumb is for AVE results to be $\geq 0.50$ (Fornell and Larcker, 1981). The minimum value generally accepted for a reliable construct is CRI $\geq 0.70$ (Fornell and Larcker, 1981). We reported values (for AVE 0.55, 0.70 and 0.63) and (for CRI 0.83, 0.87 and 0.87) for CWSS, OID and ESI respectively.

Confirmatory factor analysis (CFA) was conducted to test the consistency of our measurement model. Our three-factor model reported the best fit: $X^{2}=1173.57, d f=$ $116, p<0.001$, NFI .92, TLI .91, CFI .93 and RMSEA .05 compared to a two-factor and one-factor model. In the two-factor model, all items on CWSS and ESI were loaded together to form a single factor and measured alongside OID: $X^{2}=1767.53, d f=118, p<0.001$, NFI .80, TLI .76, CFI .81 and RMSEA .10. The one factor model had all items loaded on the same factor: $X^{2}=2934.195, d f=119, p<0.001$, NFI .67, TLI .59, CFI .68 and RMSEA .12 (Marsh et al., 2004, Podsakoff et al., 2003). We judge the best fit indices using the conventional cut off values of good fit (NFI, TLI and CFI>.90 and RMSEA <.08) (Marsh et al., 2004).

\section{Relationship between co-worker social support and organisational identification}

In the empirical context of the study, a significant positive relationship was found between co-worker social support and organisational identification, $\beta=0.49, \mathrm{t}(1)=4.41, \mathrm{p}<.00$. (See Table 2). The adjusted $\mathrm{R}$ square value, which explains the extent to which a change in the dependent variables is due to the effect of the independent or associating variables, was 0.24 (Roberts and Russo, 2014, Galwey, 2014). Hypothesis 1 is therefore supported.

Insert Table 2 about here 


\section{Moderating role of ethnic self-identification}

In line with the objective of this study, the moderating role of ESI in the CWSS-OID relationship was investigated. Hayes' (2013) Process macro (model 1) was used for this analysis. Table 2 shows that on the overall data set, a significant negative interaction was found between CWSS and ESI on the outcome variable OID: $\beta=-0.06, \mathrm{t}(3)=-2.30, \mathrm{p}<.02$. To further investigate the negative interaction, the conditional effect of co-worker support on organisational identification was calculated at three levels ethnic self-identification, one standard deviation below the mean (low-ESI) $\beta=0.29$, at the (mean-ESI) $\beta=0.24$, and one standard deviation above the mean (high-ESI) $\beta=0.20$. All three levels reported significant p-value $<0.05$. These data indicate that higher perception of ESI are associated with weaker CWSS-OID relationship. Hypothesis 2 is therefore supported.

To examine whether an employee's ethnicity (in terms of indigene or non-may indigene) affects how ESI manifests in CWSS-OID relationship, we undertook the same analysis in a sample comprising employees of similar ethnicity only. We found that for indigenes sample, the moderation relationship was negative and but non-significant with $\beta=$ $0.20 \mathrm{t}(1)=-1.13, \mathrm{p}<.26$. However, a significant moderation effect was observed in the nonindigene sample $\beta=-0.10, \mathrm{t}(1)=-1.83, p=.05$ respectively. See Table 2 . The conditional effect of co-worker support on organisational identification on the sample of non-indigenes was calculated at three levels ESE, one standard deviation below the mean (low-ESI) $\beta=$ 0.40 , at the (mean-ESI) $\beta=0.31$ and one standard deviation above the mean (high-ESI) $\beta=$ 0.25 . All three levels reported significant $\mathrm{p}$-value $<0.05$. These data indicate that for nonindigenes higher perception of ESI is associated with weaker CWSS-OID relationship. This is further supported by the flatter slope for high ESI and steeper slope for low ESI in Figure 1. The hypothesis that the moderation of ESI on CWSS-OID relationship is weaker for 
(C) 2019, Emerald Publishing Limited. This accepted manuscript is deposited under

the Creative Commons Attribution Non-commercial International Licence 4.0 (CC BY-NC 4.0).

Any reuse is allowed in accordance with the terms outlined by the licence, here: https://creativecommons.org/licenses/by-nc/4.0/.

To reuse the AAM for commercial purposes, permission should be sought by contacting permissions@emeraldinsight.com. The final published version is available at https://doi.org/10.1108/JMP-04-2019-0232.

indigenes than for non-indigenes (Hypothesis 3) is therefore supported. We did not find significant results after controlling for tenure in organisation, sector and position in organisation in the overall data set.

Insert Figure 1 about here

\section{Contributions, implication and conclusions}

Based on the assumption that organisational identification and ethnic self-identification are competing forms of self-identification (Barron et al., 2011), we proposed a positive association between employees' perception of co-worker social support and organisational identification and that ethnic self-identification would moderate this relationship. Moreover, our investigation provides a deeper understanding of the way ESI influences CWSS-OID relationship by proposing that ESI may be dormant and not challenged for indigenes compared to non-indigenes.

We find that co-worker social support positively influenced organisational identification. Our model extends the CWSS theorisation of Farmer and Van- Dyne (2010) by suggesting that positive group interactions result in members' enhanced overall identification with their organisation. Where employees enjoy positive interactions with coworkers, they are likely to identify with the organisation as a whole. Our results complement findings from other studies that have identified positive workplace characteristics such as perceived organisational support (Edwards and Peccei, 2010, He et al., 2014, Rhoades and Eisenberger, 2002), supervisor support (Reade, 2001) and leadership (Bass et al., 2003) as antecedents of OID. We suggest a positive CWSS-OID relationship because CWSS may influence employees' view of their environmental social context by signalling what an organisation's culture and values are. 
(C) 2019, Emerald Publishing Limited. This accepted manuscript is deposited under

the Creative Commons Attribution Non-commercial International Licence 4.0 (CC BY-NC 4.0).

Any reuse is allowed in accordance with the terms outlined by the licence, here: https://creativecommons.org/licenses/by-nc/4.0/.

To reuse the AAM for commercial purposes, permission should be sought by contacting permissions@emeraldinsight.com. The final published version is available at https://doi.org/10.1108/JMP-04-2019-0232.

Our findings on the moderating role of ESI contributes to ethnic diversity literature.

Whereas existing studies have investigated the implications of ethnicity mainly in terms of the influence of different demographic categorisations (Cho and Mor Barak, 2008, Leonard et al., 2008), we focus on ethnicity in terms its meaning for individuals' sense of self-identity. Our findings showed that employees with stronger sense of ESI experience weaker CWSSOID relationship, suggesting that ESI and OID are competing forms of self-identity.

We extend the analysis further to examine whether the cultural differences, in this instance between indigenes and non-indigenes may impact on the underpinning relationships. We found that the interaction effect of ESI in CWSS-OID relationship was not significant in the sample of indigenes in contrast to a significant relationship observed in the sample of non-indigenes. These findings suggest that the influence of ESI is salient in the context of particular situational, social and historical factors (Atewologun et al, 2017). So, indigenous employees who experience congruence between their ethnic group and the prevailing ethnicity of their organisation may feel a sense of psychological safety and consequently relate freely with co-workers (Darwish and Hubber, 2003). The tensions and suspicions arising from demographic dissimilarity may not manifest and there will not be a need for sub categorisations based on ethnicity. On the other hand, non-indigenes who originate from a different ethnic and cultural context, are likely to be more sensitive to workplace relationship and compare their treatment with indigenes.

We contribute to literature by presenting a dynamic CWSS-OID relationship that is influenced by an employee's ethnic self-identification and the ethnicity mix of an organisation's employee composition.

There are clear organisational implications of this study for managers in Nigerian organisations and those in other countries with a similar demography. One of the 
(C) 2019, Emerald Publishing Limited. This accepted manuscript is deposited under

the Creative Commons Attribution Non-commercial International Licence 4.0 (CC BY-NC 4.0).

Any reuse is allowed in accordance with the terms outlined by the licence, here: https://creativecommons.org/licenses/by-nc/4.0/.

To reuse the AAM for commercial purposes, permission should be sought by contacting permissions@emeraldinsight.com. The final published version is available at https://doi.org/10.1108/JMP-04-2019-0232.

consequences of the FCP maybe heightened ethnic self-identification (Agbiboa, 2012, Pepple

et al., 2018) and we have demonstrated how this can result in a lowered sense of

organisational identification. Paradoxically, although FCP intended to foster societal unity by ensuring greater ethnic representation in organisations (Ukiwo, 2005, Musa, 2015), we find that it has exacerbated ethnicity-based categorisations at work and lowered sense of OID.

Our results showing a positive CWSS-OID relationship at different levels of ESI suggest that CWSS has the potential to mitigate the inherent bias arising from employees working with co-workers of different ethnicity. Managers are encouraged to develop a strong sense of cohesion between co-workers, and which ensure a climate that allows for employees to interact and relate socially. This might be able to improve organisational identification among those employees with strong ethnic identification. One way to achieve this is for managers and supervisors to be trained on the effective management of workplace social interactions. Such training may expose managers and supervisors to how to design task and work environment to foster social interactions. For example, designing collaborative task, sharing work spaces and providing private spaces for employees to chat (Tschan et al., 2004).

The study presented in this paper is not without limitations. For example, although there are other social identities that people may poses, our study focuses on ethnic identity. Our study has however provided a theoretical context for investigating other forms of social identities. We also note that contexts with less collectivist ideology may yield quite different results. Future studies are needed from a different context to enable comparisons and to make inferences on the effect of context. Another limitation to this study is that data was collected from a single source using a cross-sectional research design. Although we controlled for method bias and conducted appropriate tests to ensure the reliability of the study, we recommend that future studies should collect data from different sources. For example, a longitudinal design would be able to determine the relationship between CWSS and OID over 
(C) 2019, Emerald Publishing Limited. This accepted manuscript is deposited under

the Creative Commons Attribution Non-commercial International Licence 4.0 (CC BY-NC 4.0).

Any reuse is allowed in accordance with the terms outlined by the licence, here: https://creativecommons.org/licenses/by-nc/4.0/.

To reuse the AAM for commercial purposes, permission should be sought by contacting permissions@emeraldinsight.com. The final published version is available at https://doi.org/10.1108/JMP-04-2019-0232.

a period of time. Our results on the control variables warrants future investigation. We found that while the variables controlled for were in general not significant, position in organisation was significant for non-indigenes. Future qualitative study may provide explanation for this outcome.

In conclusion, this paper presents a case for organisational behaviour scholars and practitioners to pay attention to the quality of co-worker support as a dimension of organisational climate, particularly in the context of ethnically diverse organisations. The results have shown that the strength of employees' identification with their ethnicity may the subject the ethnic diversity composition of employees. The paper also provides new insight into to implications of FCP and similar policies by suggesting that increased ethnicity composition may adversely affect OID due to heightened ESI. Furthermore, the overall influence of CWSS on OID suggests that CWSS is an important variable for managers and organisational theorist. 

The final published version is available at https://doi.org/10.1108/JMP-04-2019-0232.

\section{References}

Adeosun, A. B. (2011), Federal character principle and national integration: A critical appraisal. International Journal of Politics and Good Governance, Vol. 2 No 2.4, pp. 1-13.

Agbiboa, D. E. (2012), Between corruption and development: The political economy of State robbery in Nigeria. Journal of Business Ethics, Vol 108 No 3, pp. 325-345.

Albert, S. and Whetten, D.A., 1985. Organizational identity: Research in organizational behavior. Greenwich, CT .

Alin, A. (2010), Multicollinearity. Wiley Interdisciplinary Reviews: Computational Statistics, Vol 2 No 3, pp. 370-374.

Andrews, R. \& Mostafa, A. M. S. (2017), Organizational goal ambiguity and senior public managers' engagement: does organizational social capital make a difference? International Review of Administrative Sciences, doi:10.1177/0020852317701824

Asatryan, V. S. \& Oh, H. (2008), Psychological Ownership Theory: An Exploratory Application in the Restaurant Industry. Journal of Hospitality \& Tourism Research, Vol 32 No 3, pp. 363-386.

Ashforth, B. E., Harrison, S. H. \& Corley, K. G. (2008), Identification in organizations: An examination of four fundamental questions. Journal of Management, Vol 34 No 3, pp. 325-374.

Atewologun, D., Kutzer, R., Dolder, E., Anderson, D. \& Sealy, R. (2017), Individual-level Foci of Identification at Work: A Systematic Review of the Literature. International Journal of Management Reviews, Vol 19 No 3, pp. 273-295.

Bar-tal, D. (2007), Sociopsychological foundations of intractable conflicts. American Behavioral Scientist, Vol 50 No 11, pp. 1430-1453.

Barak, M. E. M., Cherin, D. A. \& Berkman, S. (1998), Organizational and personal dimensions in diversity climate ethnic and gender differences in employee perceptions. The Journal of Applied Behavioral Science, Vol 34 No 1, pp. 82-104.

Barron, L. G., Hebl, M. \& King, E. B. (2011), Effects of manifest ethnic identification on employment discrimination. Cultural Diversity and Ethnic Minority Psychology, Vol 17 No 1, pp. 23-30.

Bass, B. M., Avolio, B. J., Jung, D. I. \& Berson, Y. (2003), Predicting unit performance by assessing transformational and transactional leadership. Journal of applied psychology, Vol 88 No 2, pp. 207-218.

Bennett, R. and Stamper, C.L., 2001. Corporate citizenship and deviancy: A study of discretionary work behavior. In Strategies and organizations in transition (pp. 265284). Emerald Group Publishing Limited.

Brickson, S. L. (2005), Organizational identity orientation: Forging a link between organizational identity and organizations' relations with stakeholders. Administrative Science Quarterly, Vol 50 No 4, pp. 576-609.

Caplan, R. D., Cobb, S. \& French, J. R. (1975), Relationships of cessation of smoking with job stress, personality, and social support. Journal of applied psychology, Vol 60 No 2, pp. 211-219.

Cho, S. \& Mor Barak, M. E. (2008), Understanding of diversity and inclusion in a perceived homogeneous culture: A study of organizational commitment and job performance among Korean employees. Administration in Social Work, Vol 32 No 4, pp. 100-126.

Chughtai, A. A. (2016), Servant Leadership and Follower Outcomes: Mediating Effects of Organizational Identification and Psychological Safety. The Journal of psychology, Vol 150 No 7, pp. 1-15.

Cole, B., Jones Iii, R. J., \& Russell, L. M. (2016), Racial dissimilarity and diversity climate effect organizational identification. Equality, Diversity and Inclusion: An International Journal, Vol 35 No 5/6, pp. 314-327.

Conner, D. (2015) Positive social identity expectations as a moderator of interpersonal justice perceptions. Journal of Management Development, Vol 34 No 4, pp. 395-405.

Consiglio, C., Borgogni, L., Di Tecco, C. \& Schaufeli, W. B. (2016), What makes employees engaged with their work? The role of self-efficacy and employee's perceptions of social context over time. Career Development International, Vol 21 No 2, pp. 125-143. 

The final published version is available at https://doi.org/10.1108/JMP-04-2019-0232.

Darwish, A.F.E. and Huber, G.L., 2003. Individualism vs collectivism in different cultures: a cross-cultural study. Intercultural Education, 14(1), pp.47-56.

D'hondt, F., Eccles, J. S., Van Houtte, M. \& Stevens, P. A. J. (2017), The Relationships of Teacher Ethnic Discrimination, Ethnic Identification, and Host National Identification to School Misconduct of Turkish and Moroccan Immigrant Adolescents in Belgium. Deviant Behavior, Vol 38 No 3, pp. 318-333.

De Roeck, K. \& Delobbe, N. (2012), Do environmental CSR initiatives serve organizations' legitimacy in the oil industry? Exploring employees' reactions through organizational identification theory. Journal of Business Ethics, Vol 110 No 4, pp. 397-412.

Doan, G. O. \& Stephan, C. W. (2006), The functions of ethnic identity: A New Mexico Hispanic example. International Journal of Intercultural Relations, Vol 30 No 2, pp. 229-241.

Dutton, J.E. and Dukerich, J.M., 1991. Keeping an eye on the mirror: Image and identity in organizational adaptation. Academy of management journal, 34(3), pp.517-554.

Edwards, M. R. \& Peccei, R. (2010), Perceived organizational support, organizational identification, and employee outcomes. Journal of Personnel Psychology, Vol 9 No 1, pp.17-26

Ellemers, N., Haslam, S. A., Platow, M. J., and van Knippenberg, D. (2003), Social identity at work: Developments, debates, directions, Psychology Press, New York.

Farmer, S. M. \& Van- Dyne, L. (2010), The idealized self and the situated self as predictors of employee work behaviors. Journal of Applied Psychology, Vol 95 No 3, pp. 503-516.

Farmer, S. M., Van- Dyne, L. \& Kamdar, D. (2015). The contextualized self: How team-member exchange leads to coworker identification and helping OCB. Journal of Applied Psychology, Vol 100 No 2, pp. 583-595.

Fornell, C. \& Larcker, D. F. (1981), Structural equation models with unobservable variables and measurement error: Algebra and statistics. Journal of marketing research, pp. 382-388.

Frenkel, S., Restubog, S. L. D. \& Bednall, T. (2012), How employee perceptions of HR policy and practice influence discretionary work effort and co-worker assistance: evidence from two organizations. The International Journal of Human Resource Management, Vol 23 No 20, pp. 4193-4210.

Galwey, N. W. (2014). Introduction to mixed modelling: beyond regression and analysis of variance, John Wiley \& Sons, West Sussex.

Gberevbie, D.E. (2010), Strategies for employee recruitment, retention and performance: Dimension of the Federal civil service of Nigeria. African Journal of Business Management, 4(8), pp.1447-1456.

Gioia, D.A., Schultz, M. and Corley, K.G., 2000. Organizational identity, image, and adaptive instability. Academy of management Review, 25(1), pp.63-81.

Goulet, L. R. \& Frank, M. L. (2002), Organizational commitment across three sectors: Public, nonprofit, and for-profit. Public Personnel Management, Vol 31 No 2, pp. 201-210.

Gountas, S., Gountas, J. and Mavondo, F.T., 2014. Exploring the associations between standards for service delivery (organisational culture), co-worker support, self-efficacy, job satisfaction and customer orientation in the real estate industry. Australian Journal of Management, 39(1), pp.107-126.

Hair, J. F., Sarstedt, M., Ringle, C. M. \& Mena, J. A. (2012), An assessment of the use of partial least squares structural equation modeling in marketing research. Journal of the academy of marketing science, Vol 40 No 3, pp. 414-433.

Hayes, A. F. (2013), Introduction to mediation, moderation, and conditional process analysis: A regression-based approach, Guilford Press, London.

He, H., Pham, H. Q., Baruch, Y. \& Zhu, W. (2014), Perceived organizational support and organizational identification: joint moderating effects of employee exchange ideology and employee investment. The International Journal of Human Resource Management, Vol 25 No 20, pp. $2772-2795$.

Hofstede, G., 1998. Attitudes, values and organizational culture: Disentangling the concepts. Organization studies, 19(3), pp.477-493. 
Hwa, M. A. C. (2012), Emotional Labor and Emotional Exhaustion: Does Co-worker Support Matter? Journal of Management Research, Vol 12 No 3, pp. 115-127.

Joiner, T. A. (2007), Total quality management and performance: The role of organization support and co-worker support. International Journal of Quality \& Reliability Management, Vol 24 No 6, pp. 617-627.

Jones, C. \& Volpe, E. H. (2011), Organizational identification: Extending our understanding of social identities through social networks. Journal of organizational Behavior, Vol 32 No 3, pp. 413434.

Judge, T.A. and Kammeyer-Mueller, J.D., (2012), Job attitudes. Annual review of psychology, Vol 63, pp. 341-367

Kendhammer, B. (2014), Citizenship, federalism and powersharing: Nigeria's federal character and the challenges of institutional design. Ethnopolitics, Vol 13 No 4, pp. 396-417.

Kennedy, B. (2014), Unraveling representative bureaucracy a systematic analysis of the literature. Administration \& Society, Vol 46 No 4, pp. 395-421.

Kenny, D. A. (2016), Power analsis app MedPower. Learn how you can do a mediation analysis and output a text description of your results: Go to mediational analysis using DataToText using SPSS or R. Power, Available at http://www.davidakenny.net $/ \mathrm{cm} / \mathrm{mediate} . \mathrm{htm}$.

King, E., Dawson, J. F., Kravitz, D. A. \& Gulick, L. (2012) A multilevel study of the relationships between diversity training, ethnic discrimination and satisfaction in organizations. Journal of Organizational Behavior, Vol 33 No 1, pp. 5-20.

Landis, J.R. and Koch, G.G., 1977. The measurement of observer agreement for categorical data. biometrics, pp.159-174.

Lee, H.-J. \& Reade, C. (2015), Ethnic homophily perceptions as an emergent IHRM challenge: evidence from firms operating in Sri Lanka during the ethnic conflict. The International Journal of Human Resource Management, Vol 26 No 13, pp. 1645-1664.

Leonard, A. S., Mehra, A. \& Katerberg, R. (2008), The social identity and social networks of ethnic minority groups in organizations: A crucial test of distinctiveness theory. Journal of Organizational Behavior, Vol 29 No 5, pp. 573-589.

Lyness, K.S. and Thompson, D.E., 1997. Above the glass ceiling? A comparison of matched samples of female and male executives. Journal of applied psychology, 82(3), p.359375.

Mael, F. \& Ashforth, B. E. (1992), Alumni and their alma mater: A partial test of the reformulated model of organizational identification. Journal of organizational Behavior, Vol 13 No 2, pp. 103-123.

Marique, G. and Stinglhamber, F., (2011), Identification to proximal targets and affective or organizational commitment. Journal of Personnel Psychology. Vol 10, pp. 107-117

Marsh, H.W., Hau, K.T. and Wen, Z., 2004. In search of golden rules: Comment on hypothesistesting approaches to setting cutoff values for fit indexes and dangers in overgeneralizing $\mathrm{Hu}$ and Bentler's (1999) findings. Structural equation modeling, 11(3), pp.320-341.

Md-Sidin, S., Sambasivan, M. \& Ismail, I. (2010), Relationship between work-family conflict and quality of life: An investigation into the role of social support. Journal of Managerial Psychology, Vol 25 No 1, pp. 58-81.

Musa, A. (2015), Federalism and National Integration: The Myth of the Agitations for Confederation of Ethnic Nationalities in Nigeria. Online Journal of African Affairs, Vol 4 No 1, pp. 13-25.

Nelson, D. L. \& Quick, J. C. (1991), Social support and newcomer adjustment in organizations: Attachment theory at work? Journal of organizational behavior, Vol 12 No 6, pp. 543-554.

Nyambegera, S. M. (2002) Ethnicity and human resource management practice in sub-Saharan Africa: the relevance of the managing diversity discourse. International Journal of Human Resource Management, Vol 13 No 7, pp. 1077-1090.

Olatokun, W. \& Nwafor, C. I. (2012), The effect of extrinsic and intrinsic motivation on knowledge sharing intentions of civil servants in Ebonyi State, Nigeria. Information Development, Vol 28 No 3, pp. 216-234. 
(C) 2019, Emerald Publishing Limited. This accepted manuscript is deposited under

the Creative Commons Attribution Non-commercial International Licence 4.0 (CC BY-NC 4.0).

Any reuse is allowed in accordance with the terms outlined by the licence, here: https://creativecommons.org/licenses/by-nc/4.0/.

To reuse the AAM for commercial purposes, permission should be sought by contacting permissions@emeraldinsight.com. The final published version is available at https://doi.org/10.1108/JMP-04-2019-0232.

Oruwari, Y., Owei, O. \& Jev, M. (2004), Gender, ethnicity and violence and their effects on livelihoods in the Niger Delta Region, Nigeria: The case of Keegbara-Dere (Ogoni) and Bolo (Okrika) in Rivers State. Africa media review, Vol 12 No 1, pp. 27-42.

Pepple, D. G., Davies, E. \& Davies, J. (2018), Bureaucracy and Personality: Does Ethnicity Matter? In: (ED.), A. F. (ed.) Global Encyclopedia of Public Administration, Public Policy, and Governance. Springer, Switzerland.

Pettigrew, T. F., Tropp, L. R., Wagner, U. \& Christ, O. (2011), Recent advances in intergroup contact theory. International Journal of Intercultural Relations, Vol 35 No 3, pp. 271-280.

Pfeffer, J. and Salancik, G.R. (1978) The extemal control of organizations. A Resource Dependence Perspective, New York et al.: Harper \& Row.

Phinney, J. S. (1992) The multigroup ethnic identity measure: A new scale for use with diverse groups. Journal of Adolescent research, Vol 7 No 2, pp. 156-176.

Phinney, J. S. \& Ong, A. D. (2007), Conceptualization and measurement of ethnic identity: Current status and future directions. Journal of Counseling Psychology, Vol 54 No 3, pp. 271-281.

Phinney, J.S., Horenczyk, G., Liebkind, K. and Vedder, P., 2001. Ethnic identity, immigration, and well-being: An interactional perspective. Journal of social issues, 57(3), pp.493510.

Pittman, P., Davis, C., Shaffer, F., Herrera, C.-N. \& Bennett, C. (2014) Perceptions of employmentbased discrimination among newly arrived foreign-educated nurses. The American Journal of Nursing, Vol 114 No 1, pp. 26-35.

Podsakoff, P.M., MacKenzie, S.B., Lee, J.Y. and Podsakoff, N.P., 2003. Common method biases in behavioral research: A critical review of the literature and recommended remedies. Journal of applied psychology, 88(5), p.879-903.

Prieto-Pastor, I. and Martin-Perez, V., 2015. Does HRM generate ambidextrous employees for ambidextrous learning? The moderating role of management support. The International Journal of Human Resource Management, 26(5), pp.589-615.

Pugh, S. D., Dietz, J., Brief, A. P. \& Wiley, J. W. (2008), Looking inside and out: the impact of employee and community demographic composition on organizational diversity climate. Journal of applied psychology, Vol 93 No 6, pp. 1422-1428.

Radstaak, M. \& Hennes, A. (2017). Leader-member exchange fosters work engagement: The mediating role of job crafting. SA Journal of Industrial Psychology, Vol 43 No 1, pp 1-11.

Reade, C. (2001), Antecedents of organizational identification in multinational corporations: Fostering psychological attachment to the local subsidiary and the global organization. International Journal of Human Resource Management, Vol 12 No 8, pp. 1269-1291.

Rhoades, L. \& Eisenberger, R. (2002), Perceived organizational support: a review of the literature. Journal of applied psychology, Vol 87 No 4, pp. 698-714.

Rice, G. (2006), Individual values, organizational context, and self-perceptions of employee creativity: Evidence from Egyptian organizations. Journal of Business Research, Vol 59 No 2, pp. 233241.

Roberson, Q. M. \& Stevens, C. K. (2006), Making sense of diversity in the workplace: organizational justice and language abstraction in employees' accounts of diversity-related incidents. Journal of Applied Psychology, Vol 91 No 2, 379.

Roberts, M. \& Russo, R. 2014. A student's guide to analysis of variance, Routledge, New York.

Satorra, A. and Bentler, P.M., 2001. A scaled difference chi-square test statistic for moment structure analysis. Psychometrika, 66(4), pp.507-514.

Skarlicki, D. P., Van Jaarsveld, D. D. \& Walker, D. D. (2008), Getting even for customer mistreatment: the role of moral identity in the relationship between customer interpersonal injustice and employee sabotage. Journal of applied psychology, Vol 93 No 6, pp. 1335-1347.

Sluss, D. M. \& Ashforth, B. E. (2007), Relational identity and identification: Defining ourselves through work relationships. Academy of Management Review, Vol 32 No 1, pp. 9-32.

Tajfel, H. 1974. Social identity and intergroup behaviour. Information (International Social Science Council), Vol 13 No 2, pp. 65-93.

Tajfel, H. (2010), Social identity and intergroup relations, Cambridge University Press, London. 
Tajfel, H. \& Turner, J. (1979) An integrative theory of intergroup conflict. in wg austin \& s. worchel (eds.), The social psychology of intergroup relations (pp. 33-47). Monterey, CA: Brooks/Cole.

Triana, M. D. C., Wagstaff, M. F. \& Kim, K. (2012) That's not fair! How personal value for diversity influences reactions to the perceived discriminatory treatment of minorities. Journal of business ethics, Vol 111 No 2, pp. 211-218.

Tschan, F., Semmer, N. K. \& Inversin, L. (2004), Work related and“ private"social interactions at work. Social Indicators Research, Vol 67 No 1-2, pp. 145-182.

Ukiwo, U. (2005), The study of ethnicity in Nigeria. Oxford Development Studies, Vol 33 No 1, pp. 723.

Van Dijke, M., De Cremer, D., Bos, A. E. \& Schefferlie, P. (2009), Procedural and interpersonal fairness moderate the relationship between outcome fairness and acceptance of merit pay. European Journal of Work and Organizational Psychology, Vol 18 No 1, pp. 8-28.

Varshney, A. (2003), Ethnic conflict and civic life: Hindus and Muslims in India, Yale University Press.

Wilkins, S., Butt, M. M. \& Annabi, C. A. (2018), The influence of organisational identification on employee attitudes and behaviours in multinational higher education institutions. Journal of Higher Education Policy and Management, Vol 40 No 1, pp. 48-66. 
(c) 2019, Emerald Publishing Limited. This accepted manuscript is deposited under

the Creative Commons Attribution Non-commercial International Licence 4.0 (CC BY-NC 4.0).

Any reuse is allowed in accordance with the terms outlined by the licence, here: https://creativecommons.org/licenses/by-nc/4.0/.

To reuse the AAM for commercial purposes, permission should be sought by contacting permissions@emeraldinsight.com.

The final published version is available at https://doi.org/10.1108/JMP-04-2019-0232.

Table 1: Descriptive statistics and correlation relationships among variables

\begin{tabular}{|c|c|c|c|c|c|c|c|c|}
\hline Variables & Mean & SD & ESI & CWSS & OID & $\begin{array}{c}\text { Tenure in } \\
\text { organisation }\end{array}$ & Sector & $\begin{array}{c}\text { Position in } \\
\text { organisation }\end{array}$ \\
\hline ESI & 3.88 & 0.72 & 1 & & & & & \\
\hline CWSS & 3.81 & 0.74 & $0.55 * *$ & 1 & & & & \\
\hline OID & 3.97 & 0.70 & $0.44 * *$ & $0.42 * *$ & 1 & & & \\
\hline Tenure in organisation & 2.44 & 0.77 & $0.12 * *$ & $0.10 * *$ & $0.10 * *$ & 1 & & \\
\hline Sector & 1.41 & 0.49 & $0.24 * *$ & $0.21 * *$ & $0.18 * *$ & $-0.32 * *$ & 1 & \\
\hline Position in organisation & 1.72 & 0.48 & -0.02 & -0.01 & -0.04 & $0.32 * *$ & $0.12 * *$ & 1 \\
\hline
\end{tabular}

Keys:

** Correlation is significant at the 0.01 level (2-tailed).

Tenure in the organisation (employed for 5 years and below $=1$, more than 5 years to 10 years $=2$ and greater than 10 years $=3$ ). Sector (public sector $=1$ and private sector $=2$ ). Position in organisation (junior staff $=1$, senior staff $=2$ ). 
(c) 2019, Emerald Publishing Limited. This accepted manuscript is deposited under

the Creative Commons Attribution Non-commercial International Licence 4.0 (CC BY-NC 4.0).

Any reuse is allowed in accordance with the terms outlined by the licence, here: https://creativecommons.org/licenses/by-nc/4.0/.

To reuse the AAM for commercial purposes, permission should be sought by contacting permissions@emeraldinsight.com.

The final published version is available at https://doi.org/10.1108/JMP-04-2019-0232.

Table 2: Regression output for CWSS, ESI and OID relationship for all respondent, indigenes only and non-indigenes.

\begin{tabular}{|c|c|c|c|c|c|c|c|c|c|c|c|c|c|c|c|c|c|c|}
\hline \multirow[b]{2}{*}{ Variables } & \multicolumn{6}{|c|}{$\begin{array}{l}\text { All respondents (indigenes and non-indigenes) } \\
\mathrm{N}=\mathbf{1 5 2 5}\end{array}$} & \multicolumn{6}{|c|}{ Indigenes only N=1096 } & \multicolumn{6}{|c|}{ Non-indigenes $N=429$} \\
\hline & coefficient & se & $\mathrm{t}$ & $\mathrm{p}$ & LLCI & ULCI & coefficient & se & $\mathrm{t}$ & $\mathrm{p}$ & LLCI & ULCI & coefficient & se & $\mathrm{t}$ & $\mathrm{p}$ & LLCI & ULCI \\
\hline Constant & 0.87 & 0.41 & 2.16 & 0.31 & 0.08 & 1.67 & 1.29 & 0.52 & 2.47 & 0.14 & 0.27 & 2.31 & 0.43 & 0.68 & 0.63 & 0.53 & -0.91 & 1.77 \\
\hline CWSS & 0.49 & 0.11 & 4.41 & 0.00 & 0.27 & 0.72 & 0.37 & 0.15 & 2.55 & 0.01 & 0.08 & 0.65 & 0.66 & 0.19 & 3.47 & 0.00 & 0.29 & 1.03 \\
\hline $\begin{array}{l}\text { ESI } \\
\text { CWSS X }\end{array}$ & 0.55 & 0.11 & 5.03 & 0.00 & 0.33 & 0.77 & 0.48 & 0.14 & 3.51 & 0.00 & 0.21 & 0.74 & 0.62 & 0.19 & 3.16 & 0.00 & 0.24 & 1.00 \\
\hline ESI & -0.06 & 0.03 & -2.30 & 0.02 & -0.12 & -0.08 & -0.20 & 0.04 & -1.13 & 0.26 & -0.11 & 0.03 & -0.10 & 0.05 & -1.82 & 0.05 & -0.19 & -0.07 \\
\hline $\begin{array}{l}\text { Tenure in } \\
\text { organisation }\end{array}$ & 0.02 & 0.02 & -2.39 & 0.22 & -0.12 & 0.01 & -0.07 & 0.03 & -2.52 & 0.11 & -0.14 & 0.02 & -0.02 & 0.05 & -0.50 & 0.62 & -0.12 & 0.71 \\
\hline Sector & 0.01 & 0.08 & 0.18 & 0.86 & -0.14 & 0.16 & -0.16 & 0.45 & -0.36 & 0.72 & -0.11 & 0.07 & 0.12 & 0.07 & 1.62 & 0.10 & -0.24 & 0.26 \\
\hline $\begin{array}{l}\text { Position in } \\
\text { organisation }\end{array}$ & -0.03 & 0.03 & -1.58 & 0.11 & -0.12 & 0.00 & 0.04 & 0.02 & 1.73 & 0.08 & -0.05 & 0.82 & -0.13 & 0.56 & -2.36 & 0.02 & -0.24 & -0.02 \\
\hline \multicolumn{19}{|c|}{ Conditional effect of CWSS on OID at values of ESI } \\
\hline $\begin{array}{l}\text { Levels of } \\
\text { moderator }\end{array}$ & Effect & $\mathrm{se}$ & $\mathrm{t}$ & $\mathrm{p}$ & LLCI & ULCI & Effect & se & $\mathrm{t}$ & $\mathrm{p}$ & LLCI & ULCI & Effect & se & $\mathrm{t}$ & $\mathrm{p}$ & LLCI & ULCI \\
\hline $\begin{array}{l}\text { Low level } \\
\text { ESI }\end{array}$ & 0.29 & 0.03 & 8.92 & 0.00 & 0.22 & 0.35 & 0.32 & 0.04 & 8.37 & 0.00 & 0.24 & 0.39 & 0.40 & 0.06 & 6.30 & 0.00 & 0.27 & 0.53 \\
\hline $\begin{array}{l}\text { Medium } \\
\text { level ESI } \\
\text { High level }\end{array}$ & 0.24 & 0.03 & 8.46 & 0.00 & 0.18 & 0.29 & 0.29 & 0.03 & 8.92 & 0.00 & 0.22 & 0.35 & 0.31 & 0.05 & 6.41 & 0.00 & 0.21 & 0.39 \\
\hline ESI & 0.20 & 0.03 & 5.55 & 0.00 & 0.13 & 0.27 & 0.25 & 0.05 & 5.59 & 0.00 & 0.16 & 0.34 & 0.25 & 0.61 & 4.41 & 0.00 & 0.13 & 0.37 \\
\hline
\end{tabular}

Tenure in the organisation (employed for 5 years and below $=1$, more than 5 years to 10 years $=2$ and greater than 10 years $=3$ ). Sector (public sector $=1$ and private sector $=2$ ). Position in organisation (junior staff $=1$, senior staff $=2$ ). 
Figure 1: Slope showing the moderation of CWSS-OID relationship at different levels of ESI for non-indigenes

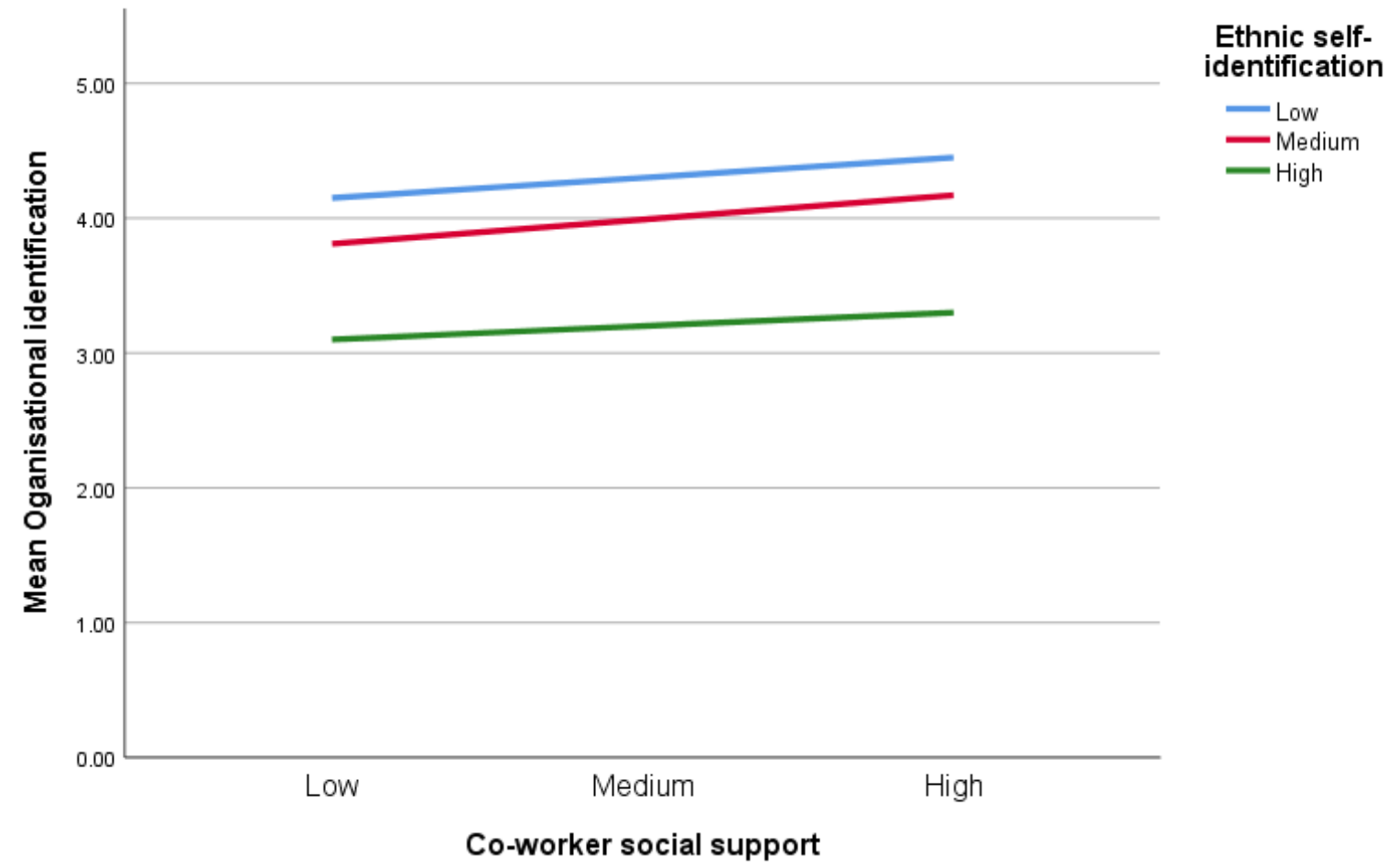

